\title{
Definition of the type material of several nominal taxa of pikas (Lagomorpha: Ochotonidae) from alpina-hyperborea group
}

\author{
Andrey A. Lissovsky, Galina I. Baranova \& Elena Yu. Ivanitskaya
}

\begin{abstract}
The original descriptions of nominal taxa of pikas of alpina-hyperborea group, described by Schrenk (1858) and Sokolov et al. (1994), so as museum collections were studied. The storing places and the collection numbers of the type series of Lagomys hyperboreus normalis Schrenk, 1858, Lagomys hyperboreus cinereoflava Schrenk, 1858 are indicated; the lectotypes of the taxa Lagomys hyperboreus ferruginea Schrenk, 1858, Ochotona hyperborea davanica Sokolov et al., 1994, Ochotona hyperborea stenorostrae Sokolov et al., 1994 and Ochotona hyperborea shamani Sokolov et al., 1994 are fixed. Some localities are defined more accurately.
\end{abstract}

KEY WORDS: Taxonomy, nomenclature, Ochotona hyperborea.

Andrey A. Lissovsky [andlis@zmmu.msu.ru], Zoological Museum of Moscow State University, Bolshaya Nikitskaya 6, Moscow 125009, Russia; Galina I. Baranova [lemmus@zin.ru], Zoological Institute, Russian Academy of Sciences, Universitetskaya nab. 1, Saint Petersburg 199034, Russia; Elena Yu. Ivanitskaya [lenaiva@hotmail.com]. Ein Shaviv 65, Mizpe Ramon 80600, Israel.

\section{Уточнение типового материала некоторых номинальных таксонов пищух (Lagomorpha: Ochotonidae) группы alpina-hyperborea}

\section{А.А. Лисовский, Г.И. Баранова, Е.Ю. Иваницкая}

\begin{abstract}
РЕЗЮМЕ. Анализируется типовой материал номинальных таксонов пищух группыalpina-hyperborea, описанных Шренком (Schrenk, 1858) и Соколовым с соавторами (1994). Указываются места хранения и музейные номера типовых серий Lagomys hyperboreus normalis Schrenk, 1858, Lagomys hyperboreus cinereoflava Schrenk, 1858; фиксируются лектотипы для Lagomys hyperboreus ferruginea Schrenk, 1858, Ochotona hyperborea davanica Sokolov et al., 1994, Ochotona hyperborea stenorostrae Sokolov et al., 1994 и Ochotona hyperborea shamani Sokolov et al., 1994. Уточняются места добычи некоторых экземпляров из типовых серий.
\end{abstract}

КЛЮЧЕВЫЕ СЛОВА: Систематика, номенклатура, Ochotona hyperborea.

\section{Introduction}

During the preparing of taxonomic revision of the pikas (Ochotona, Lagomorpha) of alpina-hyperborea group, we revealed a number of cases, when either a nominal taxon of the species group had no fixed namebearing type, while the type series was not lost and stores in one of the zoological museums or there is a vagueness in the identification of the type specimens. This is true for the following nominal taxa: Lagomys hyperboreus ferruginea Schrenk, 1858, Lagomys hyperboreus normalis Schrenk, 1858, Lagomys hyperboreus cinereoflava Schrenk, 1858,Ochotona hyperborea davanica Sokolov et al., 1994,Ochotona hyperborea stenorostrae Sokolov et al., 1994, and Ochotona hyperborea shamani Sokolov et al., 1994. The fixation of the type material for these taxa is necessary for the solution of a number of the questions in the taxonomy of alpina-hyperborea pikas.

Abbreviations used in the text: ZMMU - Zoological Museum of the Moscow State University, Moscow, Russia;
ZIN - Zoological Institute of the Russian Academy of Sciences, Saint Petersburg, Russia; ISEA - Institute of Systematics and Ecology of Animals of the Siberian Branch of the Russian Academy of Sciences, Novosibirsk, Russia; ICZN - International Code of Zoological Nomenclature; cnthe field number of specimen from collector's label; oc - the number of ZIN "old catalogue".

\section{Taxonomy}

Schrenk named the races normalis, ferruginea and cinereoflava during description of the color variation of the northern pika O. hyperborea (Pallas, 1811) pelage (Schrenk, 1858). The original spelling of these taxa was Lagomys hyperboreus var. normalis, Lagomys hyperboreus var. ferruginea and Lagomys hyperboreus var. cinereo-flava. These names are available species-group names because Schrenk clearly used the term "varietas" and did not give explicitly the infrasubspecific rank to the described taxa (Article 45.6.4, ICZN, 1999). 


\section{Ochotona hyperborea normalis Schrenk, 1858}

The nominal taxon Lagomys hyperboreus normalis Schrenk, 1858 was described by Schrenk on the base of the single specimen collected on $21(9)^{1}$ August by I.G. Voznessensky on Kholzan Mountain, Southern Kamchatka (Schrenk, 1858: 148). This specimen is the holotype of the nominal taxon Lagomys hyperboreus normalis Schrenk, 1858 (Article 73.1.2, ICZN, 1999). The depository place and the collection number of the holotype are provided here for the first time:

The holotype: ZIN 82199 (oc 690), skull and skin, male. Collected on Kholzan Mountain $\left(53^{\circ} 02^{\prime} \mathrm{N}, 157^{\circ} 30^{\prime}\right.$ E), Kamchatka, 9 August 1847, by I.G. Voznessensky.

\section{Ochotona hyperborea ferruginea Schrenk, 1858}

The nominal taxon Lagomys hyperboreus ferruginea Schrenk, 1858 was described by Schrenk on the base of two specimens collected on 15 (3) and 19 (7) August also by I.G. Voznessensky on Kholzan Mountain, Southern Kamchatka (Schrenk, 1858: 148). These specimens constitute the type series and are syntypes (Articles 72.4.1 and 73.2, ICZN, 1999). Ognev (1940: 49) mentioned the type specimen stored in the ZIN collection but did not provide its collection number or any other information which might help to identify the specimen. Moreover we cannot assert that Ognev meant only one of the two specimens indicated in the original description. One of the syntypes (stuffed specimen, ZIN 310) was donated to State Pokrovskiy teacher's training college in 1936 (the specimen returned to ZIN in 2003). However we are not sure that Ognev accomplished his description of specimens after 1936. Thus there is some vagueness in the lectotype identification, and we want to clarify this question. The fixation of the lectotype for the nominal taxon Lagomys hyperboreus ferruginea Schrenk, 1858 is necessary for the subspecific attribution of Yakutian pikas.

The lectotype: ZIN 82200 (oc 691), skin with skull inside, female. Collected on Kholzan Mountain $\left(53^{\circ} 02^{\prime}\right.$ N, $157^{\circ} 30^{\prime}$ E), Kamchatka, 3 August 1847, by I.G. Voznessensky. The paralectotype: ZIN 310, stuffed specimen with skull inside. Collected on Kholzan Mountain, Kamchatka, 7 August 1847, by I.G. Voznessensky.

\section{Ochotona hyperborea cinereoflava Schrenk, 1858}

The nominal taxon Lagomys hyperboreus cinereoflava Schrenk, 1858 was described by Schrenk on the base of three specimens each collected in distinct localities: near Maya River on 24 (12) September by I.G. Voznessensky, near Olenyek River on 13 (1) October by R. Maak, and in the vicinity of Udskoy Ostrog on 2 March (18 February) by A. Middendorf. These specimens have constituted the type series and were the syntypes till the lectotype fixation (Articles 72.1.1 and 73.2, ICZN, 1999) by Ognev (1940). He gave lectotype

${ }^{1}$ Here and later the date in the old style is given in brackets. status to the specimen ZIN oc 689 from Udskoy Ostrog. According to the Articles 73.2.2 and 74.1.3 of the ICZN, the valid designation of a lectotype permanently deprives all other specimens that were formerly syntypes of that nominal taxon of the status of syntype; those specimens then become paralectotypes. Thus the specimens from Maya River and Olenyek River should be recognized as paralectotypes. The depository place and the new collection numbers of the lectotype and paralectotypes are provided here for the first time.

Additionally, we determined more accurately locality of one of the paralectotypes. It is evident that the locality "Olenyek River" is not concrete enough: the length of this river is more than 1200 kilometers. We ascertained that R. Maak was leaving his camp on the bank of Olenyek River for the Syuryunda Lake on 2 October 1854 (Maak, 1886). The collection of pika specimens is mentioned in the text (Maak, 1886: 118). This took place near the camp of Maak, which situated on the bank of Olenyek River in 2 versts upper the mouth of Tirihtyah River. This place-name does not exist on the modern maps, but detailed maps made by Maak allow us to determine the exact position of the camp: $68^{\circ} 11^{\prime} \mathrm{N}$, $112^{\circ} 15^{\prime} \mathrm{E}$. It is to be stressed that fixation of the lectotype makes Udskoy Ostrog the restricted type locality of cinereoflava, and no other collection site indicated in the original description of that taxon has such a meaning.

The lectotype (fixed by Ognev, 1940): ZIN 82201 (oc 689), skin with skull inside, sex unknown. Collected near Udskoe ("Udskoy Ostrog"), lower Uda River, Khabarovskii Kray, 18 February 1845, by A. Middendorf. Paralectotypes: ZIN 82202, skin with skull inside, male. Collected near Maya River, Khabarovskii Kray, 12 September 1845, by I.G. Voznessensky; ZIN 82203, defective skull and skin, sex unknown. Collected on the bank of Olenyek River $\left(68^{\circ} 11^{\prime} \mathrm{N}, 112^{\circ} 15^{\prime} \mathrm{E}\right)$, Yakutia, 1 October 1854 , by R. Maak.

We encountered certain difficulties concerned the nomenclatural status of types, which were to be fixed for the nominal taxa described by Sokolov et al. (1994). This publication does not contain any unambiguous statements about specimens served as the basis of descriptions of the new taxa. For all of these taxa, descriptions of their ranges were provided, in addition to the diagnostic characters, in the following way, for example: "...Low Indigirka northern pika is known from Shamanovo and Kondakovskoe vicinities - low Indigirka River (right bank), live, probably, on the Alazeya tableland also" (Sokolov et al., 1994: 121). In other words, the regions, specimens from which were studied by the authors, were clearly outlined in this book. The part "Geographical distribution" contains a list of museums, specimens from which were studied from each locality. Thus we can reconstruct which particular specimens were referred to a particular taxon by Sokolov et al. (1994).

A special question is if we can consider these specimens belonging to the type series, as clear definition of their nomenclatural status is absent in the publication. ICZN (1999) asserts that a type series consists of all the 
specimens included by the author in the new nominal taxon, except any that the author expressly excludes from the type series, or refers to as distinct variants or doubtfully attributes to the taxon (Article 72.4.1). At the same time, for a nominal taxon of the species group established before 2000, any evidence, published or unpublished, may be taken into account to determine what specimens constitute the type series (Article 72.4.1.1, ICZN, 1999). ICZN does not maintain that direct list of the specimens constituting the type series is required for determination of the type series of the nominal taxa established before 2000. As far as the phrase like: “...the representative of taxon $a b c$ is known from locality A..." expressly means that the author included the specimens from the locality A into the taxon $a b c$, we may consider the aggregate of museum specimens described using such wording as the type series of the corresponding taxon.

All the specimens of the type series of the nominal taxon established before 2000 are automatically syntypes if neither a holotype nor a lectotype has been fixed (Article 73.2, ICZN, 1999). Thus all the type specimens fixing by us in the present paper from the type series of the nominal taxa davanica Sokolov et al., 1994, stenorostrae Sokolovet al., 1994 and shamani Sokolovet al., 1994 should have a status of a lectotype and paralectotypes (Article 74.1, 74.1.3, ICZN, 1999).

In the opinion of Ivanitskaya, one of the authors of the examining taxa, recognition of these subspecies was based on the craniometric features of adult animals exclusively. As to the coloration and other features, they were described later after formal taxonomical definition of each respective taxon. In this connection and taking into consideration provisions of the Article 72.4.1.1 of ICZN (1999), we think it reasonable to restrict the type series of the taxa in question to adult specimens with intact skulls suitable to craniometry. The task of choice of such skulls is simplified by published tables of measurements of specimens from different subspecies (Sokolov et al., 1994). These tables contain the number of specimens, used in analysis.

Recently, Formozov and Yakhontov (2003) claimed that the names under discussion of the nominal taxa established by Sokolov et al. (1994) are unavailable. Although not any evidence was provided by Formozov and Yakhontov to support this claim, we consider it important to respond to their opinion. All the new names of the taxa of species group established by Sokolovet al. (1994) are Latinized adjectives in the nominative singular of more then two letters and published in clear combination with a generic name Ochotona. Every name is accompanied with a clear definition. Consequently, original descriptions of the nominal taxa in the publication of Sokolov et al. (1994) are fully in concordance with the Articles 11.9 and 13 (ICZN 1999) and the names established there are available.

Ochotona hyperborea davanica Sokolovet al., 1994

This subspecies was based on seven specimens from Davan Pass, Baikalsky Range (Sokolov et al., 1994:
$122,123)$. The sample from this locality is deposited in the ISEA collection. The entire sample consists of 14 specimens; seven of them are adult animals with intact skulls (ISEA 31867, 31869, 31862, 31865, 80196, 80197, and 80198). These seven specimens constitute the type series of the nominal taxon Ochotona hyperborea davanica Sokolov et al., 1994 and are fixed here as the lectotype and paralectotypes. Fixation of the lectotype for the nominal taxa $O$. hyperborea davanica is necessary for the purpose of correct taxonomic allocation of pikas from northern Baikal where two species from alpina-hyperborea group live (Lissovsky, 2003).

The lectotype: ISEA 31867 (cn 218), skull and skin, male. Collected on Davan Pass $(50 \mathrm{~km}$ W from Severobaykalsk along Baikal-Amur railway) $\left(55^{\circ} 44^{\prime} \mathrm{N}\right.$, $108^{\circ} 50^{\prime}$ E), Baikalsky Range, Severobaykalsk District, Buryatian Republic, 5 August 1975, by Yu.G. Shvetsov. The paralectotypes: ISEA 31869 (cn 246), skull and skin, male, collected on 7 August 1975; ISEA 31862 (cn 252) skull and skin, female, collected on 7 August 1975; ISEA 31865 (cn 256) skull and skin, sex unknown, collected on 8 August 1975; ISEA 80196 (cn 200), skull and skin, collected on August 1975; ISEA 80197 (cn 254), skull, collected on August 1975; ISEA 80198 (cn 209), skull, collected on August 1975. The locality and collector as for the lectotype.

\section{4}

Ochotona hyperborea stenorostrae Sokolov et al.,

This subspecies was based on 12 specimens from West Tannu-Ola and East Tannu-Ola Ranges and from Akademik Obruchev Range, Tuva (Sokolovet al., 1994: $122,124)$. It is pointed out in the original description that pikas from described above region are known to the authors from 12 specimens of ZMMU, ZIN and ISEA collections (Sokolov et al., 1994: 119). Only eight specimens with intact skulls from Tannu-Ola and Akademik Obruchev Ranges are known to us as housed in these museums, seven of which are in the ISEA collection (ISEA 2292, 2293, 2295, 2297, 2299, 2300, and 2301) and one is in the ZMMU collection (ZMMU S46656). Probably the count 12 appeared in the publication by mistake. We consider these eight specimens constituting the type series of the nominal taxonOchotona hyperborea stenorostrae Sokolov et al., 1994 and fix them here as the lectotype and paralectotypes. Fixation of the lectotype for the nominal taxa $O$. hyperborea stenorostrae is necessary for identification of northern pikas from south-west edge of the range.

The lectotype: ISEA 2300 (cn 215), skull and skin, female. Collected in the vicinity of upper Narin River $\left(50^{\circ} 14^{\prime} \mathrm{N}, 96^{\circ} 22^{\prime} \mathrm{E}\right)$, Erzin District, Tuva, 27 August 1946, by E. Stolyarov. Paralectotypes: ISEA 2292 (cn 146a), skull and skin, male, collected on 25 June 1946; ISEA 2293 (cn 145a), skull and skin, male, collected on 25 June 1946; ISEA 2295 (cn 143a), skull and skin, female, collected on 25 June 1946; ISEA 2297 (cn 148a), skull, female, collected on 25 June 1946, all the previous specimens collected by A.I. Yanushevich; ISEA 
2301 (cn 144a), skull and skin, female, collected on 25 June 1946, by A. Bezsonov. All the above specimens collected in the vicinity of upper O-Hem River, KaaHem District, Tuva. The specimen 2299 (cn 232), skull and skin, male, upper Balycty-Hem River, Erzin District, Tuva, collected on 30 August 1946, by E. Stolyarov. ZMMU S-46656 (cn 216), skull and skin, female, upper Narin River 1500 m above sea level, Erzin District, Tuva, collected on 27 August 1946, by Glotov.

Ochotona hyperborea shamani Sokolov et al., 1994

This subspecies was based on 10 specimens from vicinities of Shamanovo village and Kondakovskoe village in lower part of Indigirka River, Yakutia (Sokolov et al., 1994: 121, 123). The entire sample is housed in the ZMMU. However there are 12 adult specimens in the sample instead 10 pointed in the publication. Probably two specimens were excluded from the analysis for unknown reason. After examination of the sample we found out that size of the specimen ZMMU S-65245 does not fall into the range of variation published in the original description. The skull ñondilobasal length in this specimen is $32.5 \mathrm{~mm}$, while the minimal value of this measurement determined for the race shamani by authors is $34.7 \mathrm{~mm}$. Obviously this specimen was not involved in the analysis. Another specimen ZMMU S65231 lacks one of the auditory bullae that could prevent measurement of width between auditory bullae, a feature included in the original description. Remaining 10 specimens (ZMMU S-65240, S-65242, S-65232, S65243, S-65238, S-65229, S-65228, S-65230, S-65234, and S-65236) have intact skulls and completely correspond to the original description. They are fixed here as the lectotype and paralectotypes. Fixation of the lectotype for the nominal taxa $O$. hyperborea shamani is necessary for the solving a question about a subspecific attribution of Yakutian pikas.

The lectotype: ZMMU S-65243 (cn 14), skull and skin, female. Collected in the vicinities of Shamanovo village $\left(69^{\circ} 57^{\prime} \mathrm{N}, 147^{\circ} 34^{\prime} \mathrm{E}\right)$, Indigirka River $17 \mathrm{~km}$ lower than Olenegorsk, Yakutia, 26 May 1960, by R.L. Boehme. Paralectotypes: ZMMU S-65228 (cn 50), skull and skin, female, collected on 16 June 1960; ZMMU S65229 (cn 3), skull and skin, collected on 18 May 1960; ZMMU S-65230 (cn 27), skull and skin, female, collect- ed on 31 May 1960; ZMMU S-65232 (cn 5), skull and skin, female, collected on 23 May 1960; ZMMU S65234 (cn 10), skull and skin, female, collected on 26 May 1960; ZMMU S-65236 (cn 24), skull and skin, male, collected on 31 May 1960; ZMMU S-65238 (cn 13), skull and skin, female, collected on 26 May 1960; ZMMU S-65240 (cn 16), skull and skin, male, collected on 26 May 1960; ZMMU S-65242 (cn 23), skull and skin, female, collected on 31 May 1960. All of the specimens collected in the vicinities of Shamanovo village, Indigirka River $17 \mathrm{~km}$ lower than Olenegorsk, Yakutia by R.L. Boehme.

ACKNOWLEDGEMENTS. We would like to sincerely thank E.I. Zholnerovskaya (Novosibirsk), I.Ya. Pavlinov, A.V. Sviridov (Moscow), and N.E. Dokuchaev (Magadan) for the help in different ways.

\section{References}

Formozov N.A. \& Yakhontov E.L. 2003. [Sympatry zone of alpine (Ochotona alpina) and northern (O. hyperborea) pikas on the Putorana plateau with description of new subspecies (Ochotona hyperborea naumovi ssp. n.) // Zoologicheskii Zhurnal. T.82. No.4. P.485-496 [in Russian, with English summary].

International Code of Zoological Nomenclature (Fourth Edition). 1999. London: International Trust for Zoological Nomenclature. 306 p.

Lissovsky A.A. 2003. Geographical variation of skull characters in pikas (Ochotona, Lagomorpha) of the alpina hyperborea group // Acta theriologica. Vol.48. Pt.1.P.1124.

Maak R. 1886. [Viluyskiy District of Yakutsk Region]. Part 2. St.-Petersburg: Tipographiya A. Transhela. 491 p. [in Russian].

Ognev S.I. 1940. [Mammals of the USSR and Adjacent Countries.] Vol.4. Moskva-Leningrad: Izdatel'stvo AN SSSR. 616 p. [in Russian].

Schrenk L. 1858. Reisen und Forschungen im Amur-Lande in den Jahren 1854-1856. Bd.1. Lfg.1. Einleitung. Säugethiere des Amur-Landes. St.-Petersburg: Kaiserl. Akademie der Wissenschaften. $213 \mathrm{~S}$.

Sokolov V.E., Ivanitskaya E.Yu., Gruzdev V.V. \& Heptner V.G. 1994. [Mammals of Russia and Adjacent Regions: Lagomorphs]. Moskva: Nauka. 272 p. [in Russian]. 